Article

\title{
Coopetition for Sustainable Competitiveness: R\&D Collaboration in Perspective of Productivity
}

\author{
Youngwook Ko ${ }^{1,2}$, Yanghon Chung ${ }^{1}\left[\right.$ and Hangyeol Seo ${ }^{3, *} \mathbb{C}$ \\ 1 School of Business and Technology Management, Korea Advanced Institute of Science and Technology, \\ Daejeon 34141, Korea; young@ibs.re.kr (Y.K.); coach@kaist.ac.kr (Y.C.) \\ 2 Institute for Basic Science, Daejeon 34126, Korea \\ 3 School of Business, Chungbuk National University, Cheongju 28644, Korea \\ * Correspondence: hgseo@chungbuk.ac.kr
}

Received: 18 August 2020; Accepted: 24 September 2020; Published: 27 September 2020

\begin{abstract}
This study explores the effect of coopetition on research and development (R\&D) productivity in two stages of the innovation process: (1) value creation to develop new technology and (2) value appropriation to generate profits. Using a sample from the 2010 and 2014 Korea Innovation Survey, we applied the propensity score matching methodology to control selective bias and the two-stage network data envelopment analysis methodology to measure R\&D productivity. Our findings indicate that firms who cooperate with competitors in the value creation stage have relatively higher R\&D productivity than those who do not. In contrast, firms that pursue the coopetition strategy showed relatively low $R \& D$ productivity in the value appropriation stage. Overall, this study provides a better understanding of coopetition by demonstrating its various benefits, costs, and risks.
\end{abstract}

Keywords: coopetition; value creation; value appropriation; R\&D productivity

\section{Introduction}

Firms pursue open innovation strategies to gain sustainable competitive advantage. It enables them to adapt to rapidly changing circumstances, to cope with risks related to uncertain futures and to achieve corporate sustainability, by pooling their resources and capabilities [1,2]. In addition, as economic resources are shared and utilized in open innovation, an eco-efficiency for societal sustainability can be obtained [3].

Global companies such as Sony, Samsung, Amazon and Air France have cooperated with their competitors [4-6], and this type of collaboration happens in both high-tech manufacturing sectors such as biotechnology, engineering and information technology [7-9] and services industries including finances, tourism and transportation [10-12].

This fact suggests that it is necessary to break away from dichotomizing inter-firm relationships among firms in cooperation or competition [13]. From this, researchers have invoked the necessity to evaluate a new strategic option termed 'coopetition' [14,15].

Coopetition is a situation where mutual cooperation and competition occur simultaneously. Companies collaborate with their competitors to grow conventional markets and to then maximize their own profits through competition [16]. However, a coopetition strategy embracing the two contradictory aspects of cooperation and competition would create a double-edged sword effect in terms of corporate performance enhancement [17].

Although previous studies have tackled coopetition, the following gaps appeared in the research. First, recent empirical investigations on coopetition are largely comprised of case studies. As those qualitative case studies majorly aim to formulate hypotheses and develop theories, quantitative empirical studies are required to further clarify the relationship between coopetition 
and firm performance $[15,16,18]$. Second, earlier research rarely addressed the bilateral effects that a coopetition strategy can bring to a firm's performance. Coopetition has the paradoxical nature of simultaneous interplay between cooperation and competition. Thus, it is necessary to discuss both the beneficial impacts of coopetition on firm performance and the accompanying costs and risks [19-22]. Finally, limited implications exist regarding the effects of coopetition strategies on corporate performance in the consecutive sub-phases of innovation process, especially in value creation and value appropriation stages. The innovation performance of firms can be categorized into two distinct and sequentially connected outcomes: technological advances at the value creation stage and financial harvest at the value appropriation stage, which is the eventual result of innovation. Therefore, in order to thoroughly understand the effects of coopetition on innovation performance, it is necessary to classify the innovation sub-processes and analyze whether the coopetition strategy's influence on a firm's performance varies with each sub-process $[4,23,24]$.

In order to fill the aforementioned research gaps, this study analyzed the effect of coopetition on research and development (R\&D) productivity at two stages of the innovation process: (1) the value creation stage to develop new technology and (2) the value appropriation stage to generate profits. To identify those effects, this study evaluated 636 corporate samples, based on the 2010 and 2014 Korea Innovation Survey (KIS), through a propensity score matching (PSM) methodology. For measuring innovation performance, we used the two-stage network data envelopment analysis (DEA) methodology and quantified the productivity performance of firms along the entire innovation process and the two sub-phases. Then, we used the Mann-Whitney U and Wilcoxon signed rank test as a methodology for identifying the differences between coopetition and non-coopetition groups.

The rest of this study is organized as follows. The literature review addresses the effects of coopetition strategies on the performance of value creation and appropriation. The methods explain the chosen research design and empirical methodologies, while the following section tackles the empirical analysis results. The discussion displays the contributions of the results and their relationship to previous findings. Finally, the conclusion includes the implications of this study and future research directions.

\section{Coopetition and Firm Performance}

\subsection{Inter-Firm Cooperation and Firm Performance}

Innovation is an important source of competitive advantage of firms [25-28]. However, firms sometimes struggle to achieve innovation through their own resources and capabilities $[29,30]$. In this way, companies may work with other entities to obtain external resources and capabilities needed for innovation [31]. Through this cooperation, companies can access the inaccessible knowledge and resources at a proper timing [32-34]. In the process of knowledge exchange, synergy is created by combining new resources and knowledge with oneself to develop new technology $[2,35,36]$. In addition, by combining the resources of one's own and the other, it will provide a foundation for carrying out innovative projects that require large and risky investments [37-39]. Abundant literature has confirmed that a firm's open innovation strategy, partnering with customers, suppliers, and universities or institutes, promotes its innovation performance [40-42].

\subsection{Coopetition and Firm Performance}

On the other hand, due to the advancement of technology and the spread of information technology, product life cycle has been shortened, and R\&D cost and risk of product development have risen. Such a highly competitive environment can lead to coopetition, a paradoxical situation in which firms cooperate with their direct competitors to secure competitive advantage [1,43,44]. From a resource-based view, competitors have similar resources and capabilities, because they operate in overlapping markets centered on similar products. Focal firms are also able to leverage their mutual capabilities and resources to diversify risks, achieve economies of scale, and improve productivity 
when they cooperate with direct competitors [45]. In addition, competing firms do not cooperate only to capture profits limited to conventional markets, they also aim to expand market size or create entirely new markets.

By deliberately delaying the collaboration process, competitors can cause focal firms to face a 'hold-up' situation in which they are not able to employ their knowledge and resources for other uses. This may misleadingly encourage focal firms to contribute excessive expertise and resources [31]. Furthermore, competitors may exhibit this opportunistic behavior in coopetition in order to hold most of the created value [17]. This opportunistic behavior may hinder the establishment of mutual trust, a prerequisite for successful cooperation [23]. Moreover, balancing cooperation and competition becomes more complex and an imbalance may lead to inefficient performance [46].

The contradictory situation in which competition and cooperation coexist is sometimes referred to a 'double-edged sword' in corporate performance [17]. Previous empirical research studying the effects of coopetition on performance also shows mixed results. Researchers have confirmed that coopetition positively affects efficiency, such as labor productivity and cost savings. Coopetition has also appeared to be a valid strategy for contributing to corporate return on equity (ROE) growth, and for achieving radical and incremental innovation [19]. On the other hand, other studies have shown that coopetition is more likely to fail than other types of collaboration and is not a viable strategy for achieving radical innovation [40]. Based on the mixed results about the effects of coopetition on firm's performance and productivity, mentioned above, the following research question is raised.

Research Question 1: How does a coopetition strategy affect firms' R\&D productivity?

\subsection{Coopetition and Firm Innovation Process: Value Creation and Appropriation}

Firms' innovation process is not simply linear but comprises a variety of interconnected activities through complex links and feedback loops. However, if the innovation activities of these companies are more intuitively simplified, they can divide into two sequential steps: 'Value Creation' and 'Value Appropriation' [4].

In economic terms, 'value' is defined as the amount payable from the perspective of the end consumer, but the value in the broader sense can be understood as social and private harvest by investing in certain industrial innovations. [14,47]. Value creation refers to innovation activities that increase the amount of these values, and value appropriation can be defined as firm behaviors that captures financial performance from the value created by innovations. In other words, firms need to focus not only on creating value through various kinds of innovation, but also on securing own profit in the end $[4,18,27,48]$.

\subsection{Coopetition and Firm Performance in Value Creation Stage}

From the perspective of game theory, coopetition is an activity that maximizes value creation through cooperation among competitors, to enlarge the entire current market and secure each player's share through competition in the value appropriation stage. This value creation is the first part of the innovation process, which includes activities such as R\&D, testing, and learning-by-doing, and results in new product development and process innovations. Coopetition enables firms to leverage mutual resources and capabilities for risk reduction in $R \& D$, economies of scale, higher R\&D productivity, and successful value creation, as competitors have similar resources [46]. In addition, cooperating with competitors in $R \& D$ helps firms control unintended knowledge leakage and enhance the value creation performance, through joint $R \& D$, by maximizing the inward knowledge spillover from their competitors [49-51].

On the other hand, the coexistence of cooperation and competition may hinder a firm's value creation by impeding the establishment of mutual trust, the premise of successful value creation. It also complicates the balancing process between cooperation and competition, and sometimes leads to conflict within the firm, resulting in fruitless cooperation and ineffective value creation $[46,52,53]$. 
In this respect, some previous studies have confirmed that coopetition can have a negative impact on a firm's value creation performance. In particular, coopetition has no significant impact on new product development performance. Additionally, cooperation with other partners, such as suppliers or customers, has a positive impact on the novelty of a product, while cooperation with competitors can have a negative impact and can undermine radical innovation [40].

On the contrary, numerous evidence-based studies insist that coopetition positively influences a firm's value creating performance, such as the development of new products with high novelty levels, radical innovation, establishing industry standards and platforms, and architectural innovation [54]. Thus, prior literature shows mixed results regarding the effect of coopetition on performance in the value creation stage. As the previous studies about how coopetition strategy affects firm's performance and productivity in value creation stage do not show aligned consequences, a research question below is posed.

Research Question 2. How does a coopetition strategy influence firms' R\&D productivity at the value creation stage?

\subsection{Coopetition and Firm Performance in Value Appropriation Stage}

At the value appropriation stage, each participant in the coopetition tries to seize the created value. This value appropriation activity corresponds to the later part of the innovation process and can be defined as financial performances, such as sales and operating profit based on new products and process innovation performance $[55,56]$.

Marketing information on the focus market is essential to capture the created value. Such information can be obtained from customers, suppliers, or competitors. However, market information obtained through cooperation with customers is myopic and poorly predictive [57]. Besides, suppliers do not play a major role in promoting focal firms' market performance, because their distance from the market is greater than the focal firms' [58].

On the other hand, competitors operate in a same market context and take a similar approach; thus, in cooperation with competitors, firms acquire the closest external knowledge to the market [45]. In other words, companies can work together with competitors to acquire the market information necessary for product sales and marketing and improve market-based financial performance [59].

Furthermore, firms maximize the utilization of pooled resources through co-branding and cross-selling with competitors in the stage of value appropriation and create high market performance. Companies create new markets through coopetition, thereby broadening consumer choice and promoting financial performance [60]. This theoretical explanation is supported by several empirical studies showing that coopetition positively influenced an increase in sales under firms' same input levels, market performance based on innovative products, market share expansion, and a radical change in business model [61].

However, if the appropriability regime is too weak to secure the value created through the process of cooperating with competitors, or if no proper strategy exists to differentiate the jointly created products, then the value appropriation of the focal firms will be hindered [31]. This issue intensifies if a superior reputation or brand image is not present. Also, the unintended leakage of knowledge, arising from the process of coopetition, can strengthen the competitors' position in the market. This may ultimately lead to a deterioration in market performance [59].

In this regard, empirical studies agree that coopetition can hinder a firm's value appropriation performance. A strong partnership with competitors can have a negative impact on ROE based on innovation performance. Collaboration with customers and suppliers has a positive impact on the proportion of sales based on innovative products, but this does not occur when working with competitors [41,62]. Tsai and Hsieh [63] have also demonstrated that, when a firm cooperates with competitors, the higher the technological competence of the focal firms, the lower the percentage of sales from innovative products. Since the prior literature connecting collaboration with competitors 
and the firm's performance and productivity does not demonstrate a conversed conclusion, the third research question is brought up.

Research Question 3. How does a coopetition strategy influence firms' R\&D productivity at the value appropriation stage?

\section{Methods}

\subsection{Research Design}

The aim of this study is to compare firm performance in terms of R\&D productivity contingent on whether firms cooperate with their competitors throughout the innovation process. To answer three research questions demonstrated in the literature review, an analysis procedure was set as shown in Figure 1.

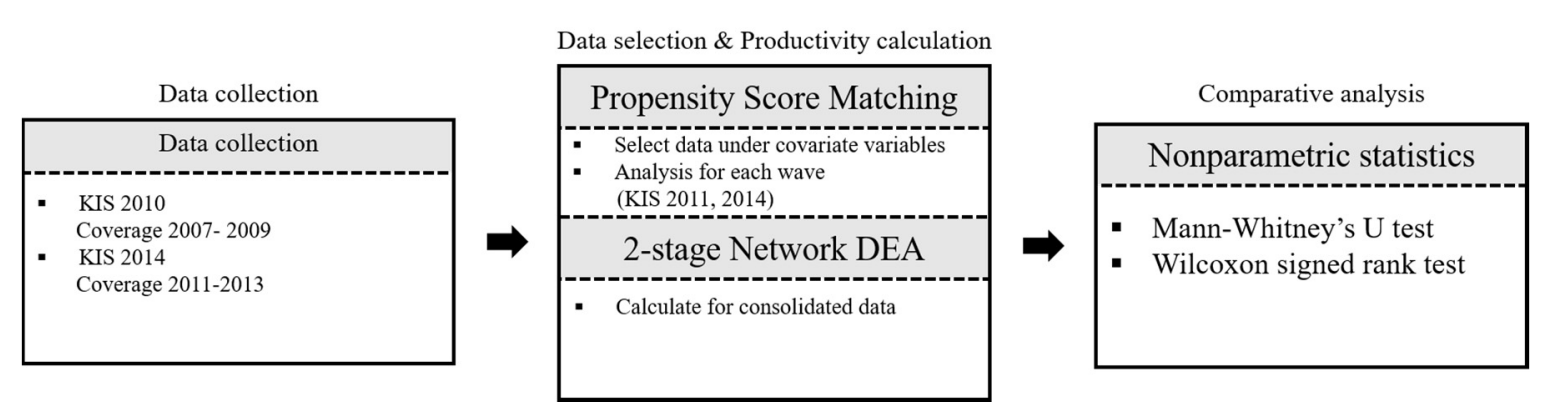

Figure 1. Diagram of analysis procedure.

The reasons for designing this research procedure are as follows. First, relatively few examples of firms that cooperate with competitors exist compared to those that do not. However, this study used two waves of KIS to collect a sufficient number of samples. Second, for accurate R\&D productivity comparisons in the coopetition and non-coopetition group, the firms' internal and external conditions, such as size, innovation strategies, and industrial characteristics, should be set identical. This required the control of endogeneity and intrinsic factors in the experimental and control group samples. We used the PSM methodology, a statistical sample selecting technique, to attempt to control sample selection bias and causal inference. Lastly, we used the two-stage network DEA methodology, comprised of inputs, intermediates, and outputs, to measure the productive efficiencies in the value creation and appropriation stages. This research defines the value creation stage as creating output, such as technology and knowledge, by inputting the financial resources and internal capabilities of the firm. The value appropriation stage is defined as deriving the financial outcome from the inputs and outputs of the value creation stage.

\subsection{Methodology}

\subsubsection{Propensity Score Matching}

For an accurate comparison between the coopetition group's and the non-coopetition group's performance, we controlled the internal factors of each. This was essential to verify the coopetition strategy's real effect on the performance of the firm. For instance, a firm may conduct cooperative R\&D with other types of partners, such as suppliers, customers, or university/research institutes, while it collaborates with its competitors. Moreover, complement factors, such as R\&D capacity, firm size and historical performance, may affect the firm's performance, and this makes the net effect of the coopetition strategy on the firm's performance more imprecise [64].

Therefore, a non-coopetition group, with similar attributes to that of the coopetition group (experimental group), was set as a control group. The PSM was the proper methodology to achieve this. 
The underlying logic of PSM is to form a control group by extracting samples containing the most similar characteristics and conditions as the samples in the experiment group. Specifically, the control group was established through the following procedure. The propensity score of each sample was calculated based on the observable covariates of the non-coopetition samples. Based on this, a sample with the most similar conditions to the specific sample in the experimental group was selected, paired with the sample, and included in the control group. From this, PSM can control the selective bias problem that might inaccurately estimate the real effect of the treatment [65].

\subsubsection{Two-Stage Network DEA}

DEA, developed by Charnes, Cooper, and Rhodes [66], is used to measure the relative productive efficiency of peer decision-making units (DMUs), which consist of multiple inputs and outputs, by estimating the ratio of weighted outputs to weighted inputs and comparing it with other DMUs. Since DEA is a non-parametric approach, it does not require any assumptions on the functional form $[67,68]$. The two-stage DEA is a methodology, introduced by Seiford and Zhu [69], for evaluating DMUs through two-stage processes with intermediate measures. In the practical world, it is hard to reflect the presence of intermediates from the direct connection between inputs and outputs [70]. Thus, the two-stage DEA can reveal the real world more adequately and offer practical insights into the productivity of firms [71]. Seiford and Zhu [69] applied the Banker's equation in a two-stage DEA model, using output-oriented variable returns to scale (VRS) for solving the scale efficiency problem, which is incurred from the large differences in DMUs' scales. Many studies have used two-stage DEA for analyzing an organization's productivity or efficiency in various research areas, such as banking, renewable energy, and innovation management $[70,72,73]$.

\subsection{Sample and Variable}

As stated previously, to obtain sufficient sample numbers, this study used two waves of KIS, a survey that comprehensively encompasses information related to innovation activities, outcomes in terms of innovation and market performance, and business circumstances. Its objective is to support evidence-based policy making in Korean firms' innovation promotion by providing survey data. The survey, which is approved by the government agency "Statistics Korea", follows the terms and definitions documented in the Organization for Economic Cooperation and Development (OECD), Oslo Manual (3rd edition), and borrows main questionnaires from the Community Innovation Survey (CIS). Thus, the KIS provides reliable and proper data for firm-level empirical research [42,74]. KIS 2010 covers the innovation activities from 2007 to 2009 and KIS 2014 is a questionnaire covering 2011 to 2013. By using two waves of KIS, we intended to increase the reliability of the results by analyzing data that are long enough. In addition, detailed financial data were collected from KISVALUE, which is a financial database. To create control groups, we conducted PSM twice: once for pairing coopetition and non-coopetition samples in KIS 2010, and then for coupling coopetition and non-coopetition samples in KIS 2014.

Based on the added value of the manufacturing industry in 2019, Korea is the world's 5th largest industrial producer [75]. Korean manufacturing firms are improving their technological competitiveness in the global market, and their influence in the international economic market is gradually increasing [76]. Accordingly, Korean manufacturing firms are attracting academic interest in various management fields such as innovation, strategy, etc., of the FT 45 Journal, and many empirical studies have also been published. [77,78]. From this, it is considered that empirical research for Korean manufacturing firms has sufficient academic value for the study of technology management.

The covariates used in PSM were selected as follows. ROA, ROE, and leverage, which are prior to innovation activities and financial indicators, are considered to reflect past financial characteristics. The values for those covariates correspond to the year prior to innovation activity. We collected the sample firms' 2006 financial data in KIS 2010 from ROE, ROA, and Leverage in the KISVALUE database, because KIS 2010 covers firms' innovation activities from 2007 to 2009 . We collected 2010 data from the 
samples in KIS 2014, which covers from 2011 to 2013. Furthermore, to control a firm's internal and external attributes, the firm size, obstacles for innovation, appropriability regime, and technological level of industry it is involved in were taken into consideration as covariates. To control other strategic characteristics during the innovation process, we also considered collaboration with other types of partners, and performing other innovation activities other than product and process innovation as covariates. The definition of the variables, measurement, and the results of the PSM balancing test are included in the Appendices A and B.

As described above, this study measured the $R \& D$ productivity of the innovation process and divided it into two stages using the two-stage network DEA methodology: value creation and appropriation. For analysis, we used three types of variable: (1) the input (first stage), (2) the intermediate (result of the first stage and investment for second stage), and (3) the output (consequence of second stage and entire innovation process). Based on those variables, we calculated two productivity values for each sample. Figure 2 illustrates those variables along the entire innovation process.

\section{R\&D Productivity}

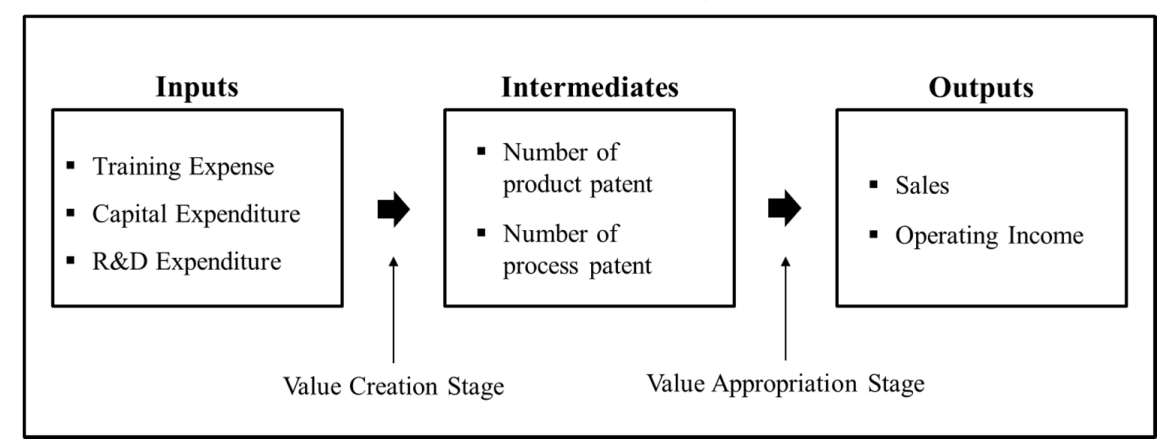

Figure 2. Productivity measurement in innovation processes.

The value creation stage's input indicators included innovation-related investments, such as training expenses, capital expenditure, and R\&D expenditure. The three input indicators for 2007 were taken into account for the KIS 2010 sub-samples, and the values for 2011 were considered for the KIS 2014 sub-samples. The number of applied patents related to product and that concerned process were considered the output indicators in the value creation stage. Those patent numbers were calculated by summing up the numbers of relevant applied patents during the survey's target period. For example, for the samples collected in KIS 2010, we summed the number of patents applied from 2007 to 2009 to derive the value of each type of patent output variable.

In the value appropriation stage, both input and output indicators of the value creation stage were considered as the input. The sales and operating income were output indicators in the appropriation stage. This analysis assumed the existence of a two-year time-lag between a firm's innovation activities and their financial outcome. In KIS 2010, the output indicators were financial data for 2009. Regarding the values of financial outcome variables for the KIS 2014 sub-samples, the 2013 numbers in KISVALUE data were matched. Other variable values, except for those financial variables, were collected from the KIS. We listed the source and year of values for all the variables used in this research in Appendix A.

\section{Results}

\subsection{Descriptive Statistics}

Table 1 shows descriptive statistics of the variables used in this research. The numbers statistics include the DEA variables and the PSM covariates. The covariates statistics display the selected samples after PSM methodology procedure. 
Table 1. Descriptive statistics.

\begin{tabular}{|c|c|c|c|c|c|c|c|}
\hline & & Variable & Mean & Std.Var & Min & Median & Max \\
\hline \multirow{7}{*}{ DEA } & \multirow{3}{*}{ Input } & Training & $311,422,959$ & $1,159,299,216$ & 0 & $22,838,000$ & $15,300,000,000$ \\
\hline & & Capital Exp & $2,937,686,764$ & $9,387,748,055$ & 0 & $768,000,000$ & $190,000,000,000$ \\
\hline & & R\&D Exp & $3,669,388,154$ & $14,794,236,493$ & 0 & $499,500,000$ & $176,000,000,000$ \\
\hline & \multirow{2}{*}{ Immediate } & Prod_patent & 38 & 246 & 0 & 2 & 4723 \\
\hline & & Proc_patent & 9 & 89 & 0 & 0 & 1800 \\
\hline & \multirow{2}{*}{ Output } & Sales & $424,259,481,769$ & $1,744,062,437,385$ & $1,323,422,000$ & $86,832,146,000$ & $27,000,000,000,000$ \\
\hline & & Operating Income & $321,754,718,793$ & $178,663,049,713$ & 1 & $296,385,000,001$ & $3,443,000,000,001$ \\
\hline \multicolumn{2}{|c|}{ Group variable } & Coopetition & 0.5 & 0.5 & 0 & 0.5 & 1 \\
\hline \multirow{9}{*}{\multicolumn{2}{|c|}{ Covariates for PSM }} & ROA & 5.573567 & 10.40268 & -71.114 & 4.749306 & 86.63258 \\
\hline & & $\mathrm{ROE}$ & 11.74681 & 26.31503 & -286.921 & 10.95723 & 186.38 \\
\hline & & Leverage & 0.541882 & 0.317271 & 0.012343 & 0.544877 & 6.148143 \\
\hline & & Size & 5.510895 & 1.150836 & 1.94591 & 5.413873 & 10.13888 \\
\hline & & Other cooperation & 0.855346 & 0.352029 & 0 & 1 & 1 \\
\hline & & Other innovation & 0.855346 & 0.352029 & 0 & 1 & 1 \\
\hline & & Innovation obstacle & 0.376208 & 0.20676 & 0 & 0.402083 & 1 \\
\hline & & Appropriability regime & 0.387114 & 0.242627 & 0 & 0.371429 & 1 \\
\hline & & Level of technology intensity & 0.633648 & 0.482187 & 0 & 1 & 1 \\
\hline
\end{tabular}

$\mathrm{n}$ = 636; Training = Training Expenses. Capital Exp. = Capital Expenditure. Prod_Patent. = Patent through product innovation. Proc_Patent. = Patent through process innovation. 
Table 2 shows the correlation between DEA variables. Sales and operating income, which are the variables related to firms' financial performance, have a significant correlation with facility investment and training expenses, but no statistical significance with R\&D expenditure. However, R\&D expenditure and both types of patent application have a significant positive correlation. Moreover, product-related patents show a significant positive correlation with process-related patents, which means that the firms perform both product innovation and process innovation simultaneously.

Table 2. Pearson correlation matrix.

\begin{tabular}{|c|c|c|c|c|c|c|c|}
\hline & Training & Capital Exp & R\&D Exp & Prod_patent & Proc_patent & Sales & OI \\
\hline Training & 1 & & & & & & \\
\hline Capital Exp & $0.58^{* * *}$ & 1 & & & & & \\
\hline R\&D Exp & -0.02 & -0.03 & 1 & & & & \\
\hline Prod_patent & -0.04 & -0.05 & $0.69^{* * *}$ & 1 & & & \\
\hline Proc_patent & -0.04 & -0.04 & $0.60^{* * *}$ & $0.59^{* * *}$ & 1 & & \\
\hline Sales & $0.81^{* * *}$ & $0.49^{* * *}$ & -0.02 & -0.04 & -0.04 & 1 & \\
\hline OI & $0.84^{* * *}$ & $0.49^{* * *}$ & -0.01 & -0.02 & -0.01 & $0.91 * * *$ & 1 \\
\hline
\end{tabular}

\subsection{Comparative Analysis Results}

Table 3 shows the comparison and verification results of the difference in R\&D productivity depending on whether firms pursue coopetition in each innovation process stage. We implemented the Mann-Whitney U test for this analysis. Since the productivity score calculated by DEA cannot be used in parametric statistics methodology, a non-parametric test was performed by ranking the productivity score. Therefore, sample firms with high productivity have lower rankings and group with lower average rankings is more efficient.

Table 3. Research and development (R\&D) productivity throughout value creation and appropriation stage.

\begin{tabular}{cccccc}
\hline 2-Stage & Strategic Position & N & Average of Ranking & Sum of Ranking & Z \\
\hline \multirow{2}{*}{ Value creation stage } & Non-coopetition & 318 & 336.19 & 106907 & $-2.449^{* *}$ \\
& Coopetition & 318 & 300.81 & 95659 & \\
Value appropriation stage & Non-coopetition & 318 & 294.85 & 93762 & $-3.246^{* * *}$ \\
\hline \multicolumn{7}{c}{-value: ${ }^{* * *}<0.01^{* *}<0.05,^{*}<0.1 ;$ Value creation stage: Mann-Whitney's U (44938), Wilcoxon's W (95659); } \\
Value appropriation stage: Mann-Whitney's U (43041), Wilcoxon's W (93762).
\end{tabular}

Results of the ranking comparison between coopetition and non-coopetition groups in the value creation stage show that the coopetition group is more productive than the latter group at the $2 \%$ significance level ( $z$-value 2.449). On the other hand, in the value appropriation stage, firms that perform a coopetition strategy are less efficient than non-coopetition groups at a $2 \%$ significance level (z-value 3.246).

These results demonstrate that firms that pursue the coopetition strategy in the value creation stage perform $R \& D$ activities more efficiently than the non-coopetition group. However, in the value appropriation stage, the R\&D productivity of firms performing a coopetition strategy is lower than that of non-coopetition groups.

Table 4 shows the analysis results regarding how the R\&D productivity of the coopetition and non-coopetition firms changes in the sequential innovation process from value creation to value appropriation. This table is the result of Wilcoxon signed rank test. The coopetition group showed a decrease in R\&D productivity during the process from value creation to value appropriation, which was confirmed with the significance level of less than $2 \%(z$-value -3.582$)$. On the other hand, regarding the non-coopetition group, productivity deterioration during the innovation process from 
value creation to value appropriation did not show a statistically significant level. The sample analysis as a whole indicates that productivity declines at the value appropriation stage, which is confirmed with a significance level of $10 \%$. These results show that a firm's coopetition strategies can have a negative impact on corporate productivity at the value appropriation stage.

Table 4. R\&D productivity throughout value creation and appropriation stage.

\begin{tabular}{|c|c|c|c|c|c|}
\hline & \multicolumn{4}{|c|}{ Value Appropriation Stage - Value Creation Stage } & \multirow{2}{*}{$\mathbf{Z}$} \\
\hline & Sign & $\mathbf{N}$ & Average of Ranking & Sum of Ranking & \\
\hline \multirow{3}{*}{ Coopetition Group } & Positive & 155 & 200.33 & 31051.50 & \multirow{3}{*}{$-3.582 * * *$} \\
\hline & Negative & 162 & 119.45 & 19351.50 & \\
\hline & Same & 1 & & & \\
\hline \multirow[b]{2}{*}{ Non-coopetition Group } & Positive & 124 & 189.07 & 23444.50 & \multirow[b]{2}{*}{-1.076} \\
\hline & $\begin{array}{c}\text { Negative } \\
\text { Same }\end{array}$ & $\begin{array}{c}193 \\
1\end{array}$ & 139.68 & 26958.50 & \\
\hline \multirow[b]{2}{*}{ Overall } & Positive & 279 & 391.19 & 109142.00 & \multirow[b]{2}{*}{$-1.841 *$} \\
\hline & Negative & 355 & 259.59 & 92153.00 & \\
\hline
\end{tabular}

\section{Discussion}

As the results showed, the R\&D productivity in the coopetition group is higher than the non-coopetition group at the value creation stage and lower in the value appropriation stage. Firms that cooperate with competitors in the value creation stage have relatively higher R\&D productivity than otherwise. In other words, cooperation with competitors achieves higher innovation performance under the same resource conditions. As competitors have similar knowledge and resources, they also use it in similar ways. Thus, companies can share the required resources and capabilities to create technological breakthroughs through coopetition. Moreover, if strong competition and strong cooperation exist simultaneously, the stability of solidarity with competitors strengthens and creates common values. This result is supported by previous studies $[54,79]$. However, in the value appropriation stage, the coopetition firms showed relatively low R\&D productivity. In other words, coopetition under the same resource conditions creates comparably poor market performance than otherwise. Coopetition poses a variety of risks, including loss of competitive advantage due to unintended leakage of knowledge and failure to secure adequate value due to partners' opportunistic behaviors. Moreover, coopetition aims to develop products that open new markets, rather than to enhance sales based on conventional markets. Thus, coopetition may have a negative impact on market performance in the securing of value (sales). Similar results have also been demonstrated in several previous studies $[7,52,80]$. These elaborations imply that coopetition is a more effective strategy in creating value for innovation; however, this is not the case in value appropriation. In other words, as previous studies have claimed, coopetition is a 'double-edged sword' with regards to a firm's performance [17].

This study contributes to current coopetition research as follows. First, as the coopetition strategy's impact on performance was analyzed by an empirical-quantitative method, it helped to identify the practical validity of the theories presented in previous conceptual and exploratory research. Second, in contrast to prior literature that separately examined the unidirectional effect (e.g., positive or negative) of a coopetition strategy on firm performance $[16,20]$, this study discussed various influential aspects of coopetition, such as benefits, cost, and risk. In other words, it provides a comprehensive view of the relationship between coopetition and performance. Finally, our results indicated that a coopetition strategy has a positive effect on $R \& D$ productivity at the value creation stage and a negative effect at the value appropriation stage. 


\section{Conclusions}

This study evaluated the coopetition strategy's effect on R\&D productivity at two innovation stages: value creation and value appropriation. Although previous literature explaining the effect of coopetition on firm performance exists, it rarely empirically tackled the bilateral effects that coopetition can bring to the innovation process.

Through our research, we extended the understanding of coopetition strategies as follows. First, we confirmed the forecasted phenomena presented in conventional exploratory and empirical research based on qualitative case studies, clearly showing how a coopetition strategy influences firm performance in the business field. Second, we examined the various effects of coopetition strategies, such as benefits, cost, and productivity as performance under the same cost conditions. Based on this, we presented a more comprehensive view of the coopetition effect on firm performance. Third, we examined the effects of coopetition on a firm's performance through each stage (value creation and appropriation), the consecutive sub-phases of the innovation process. We found that coopetition can contribute to productivity improvement at the value creation stage, but not at the value appropriation stage. In other words, firms are required to formulate how they capture created values to be successful in the coopetition strategy. For this, appropriability regimes such as patenting, lead time, trade secret, and investment in complementary assets should be established [73].

On the other hand, this research has the following limitations. This study analyzed the effects of coopetition strategies on productivity, but the research scope was limited to cooperation in product and process innovation. The coopetition for organization and marketing innovation could be a strategic mean for enhancing innovation capability, but our analysis did not address this mechanism. Furthermore, the case of cooperation with competitors from different countries was not considered in this analysis. Since the inherent factors arising from organizational differences are closely related to knowledge exchange, these issues should be considered in perspective of the productivity. In this respect, previous literature suggested appropriate hazards, technological traits and organizational differences as factors resulting in failure. An empirical analysis of how these elements can affect the relationship between coopetition and performance can provide important implications for future coopetition research.

Author Contributions: H.S. and Y.K. designed and analyzed the research; Y.C. discussed the results. All authors have read and agreed to the published version of the manuscript.

Funding: This research received no external funding.

Conflicts of Interest: The authors declare no conflict of interest. 
Appendix A Variable Measurement

\begin{tabular}{|c|c|c|c|c|c|c|}
\hline \multicolumn{2}{|c|}{ Category } & Variable & Description & Year & Unit & Source \\
\hline \multirow{3}{*}{\multicolumn{2}{|c|}{ Input }} & Training & Financial status & \multirow{3}{*}{$\begin{array}{l}2007 \text { (KIS 2010) } \\
2011 \text { (KIS 2014) }\end{array}$} & \multirow{3}{*}{ Won } & \multirow{3}{*}{$\begin{array}{l}\text { KIS } \\
\text { VALUE }\end{array}$} \\
\hline & & Capital Exp & Financial status & & & \\
\hline & & R\&D Exp & Financial status & & & \\
\hline & \multirow{2}{*}{ Immediate } & Prod_patent & Patent through product innovation & \multirow{2}{*}{$\begin{array}{l}\text { Sum of 2007-2009 } \\
\text { Sum of 2011-2013 }\end{array}$} & \multirow{2}{*}{ Num } & \multirow{5}{*}{ KIS } \\
\hline & & Proc_patent & Patent through process innovation & & & \\
\hline & \multirow{2}{*}{ Output } & Sales & Financial status & \multirow{2}{*}{$\begin{array}{l}2009 \text { (KIS 2010) } \\
2013 \text { (KIS 2014) }\end{array}$} & \multirow{2}{*}{ Won } & \\
\hline & & Operating Income & Financial status & & & \\
\hline \multicolumn{2}{|c|}{ Group variable } & Coopetition & 1 if the firm cooperate with competitor, else 0 & $\begin{array}{l}2007-2009 \text { (KIS 2010) } \\
2011-2013 \text { (KIS 2014) }\end{array}$ & Dummy & \\
\hline \multirow{9}{*}{\multicolumn{2}{|c|}{ Covariates for PSM }} & ROA & Return on Assets in previous year & \multirow{4}{*}{$\begin{array}{l}2006 \text { (KIS 2010) } \\
2010 \text { (KIS 2014) }\end{array}$} & \multirow{4}{*}{ Ratio } & \multirow{4}{*}{$\begin{array}{c}\text { KIS } \\
\text { VALU! }\end{array}$} \\
\hline & & $\mathrm{ROE}$ & Return on Equity in previous year & & & \\
\hline & & Leverage & Ratio of total debt to total asset in previous year & & & \\
\hline & & Size & Logarithm of number of employees & & & \\
\hline & & Other cooperation & 1 if the firm cooperate with other organization (except for competitor), else 0 & \multirow{4}{*}{$\begin{array}{l}\text { 2007-2009 (KIS 2010) } \\
\text { 2011-2013 (KIS 2014) }\end{array}$} & Dummy & KIS \\
\hline & & Other innovation & $\begin{array}{l}1 \text { if the firm efforts to other innovation activities except for product \& process } \\
\text { innovation, else } 0\end{array}$ & & Dummy & KIS \\
\hline & & Innovation obstacle & $\begin{array}{l}\text { Ratio of important } 4 \text { hampering factors to innovation over total score } \\
\text { (financial, capability, market, innovation needs) }\end{array}$ & & Ratio & KIS \\
\hline & & $\begin{array}{l}\text { Appropriability } \\
\text { regime }\end{array}$ & $\begin{array}{l}\text { Ratio of important appropriation methods over total score } \\
\text { (patent, secrecy, lead-time, complexity of design) }\end{array}$ & & Ratio & KIS \\
\hline & & $\begin{array}{l}\text { Level of technology } \\
\text { intensity }\end{array}$ & High-tech or Low-tech industry base the classification from OECD & - & Nominal & KIS \\
\hline
\end{tabular}




\section{Appendix B PSM Results}

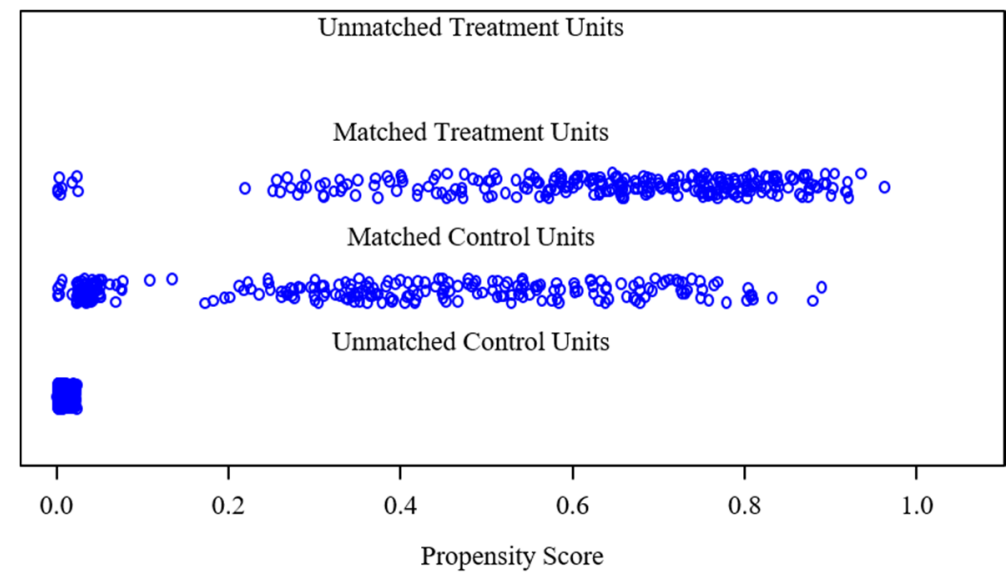

Figure A1. Distribution of propensity score (KIS 2010).
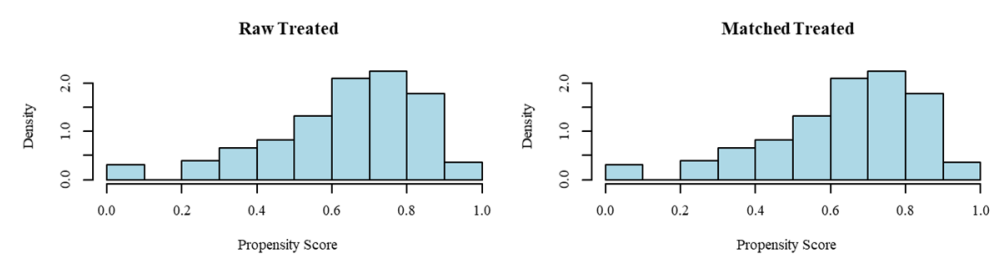

Raw Control

Matched Control
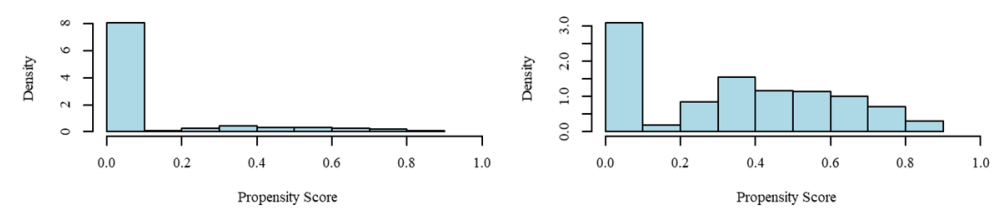

Figure A2. Histogram of propensity score (KIS 2010).

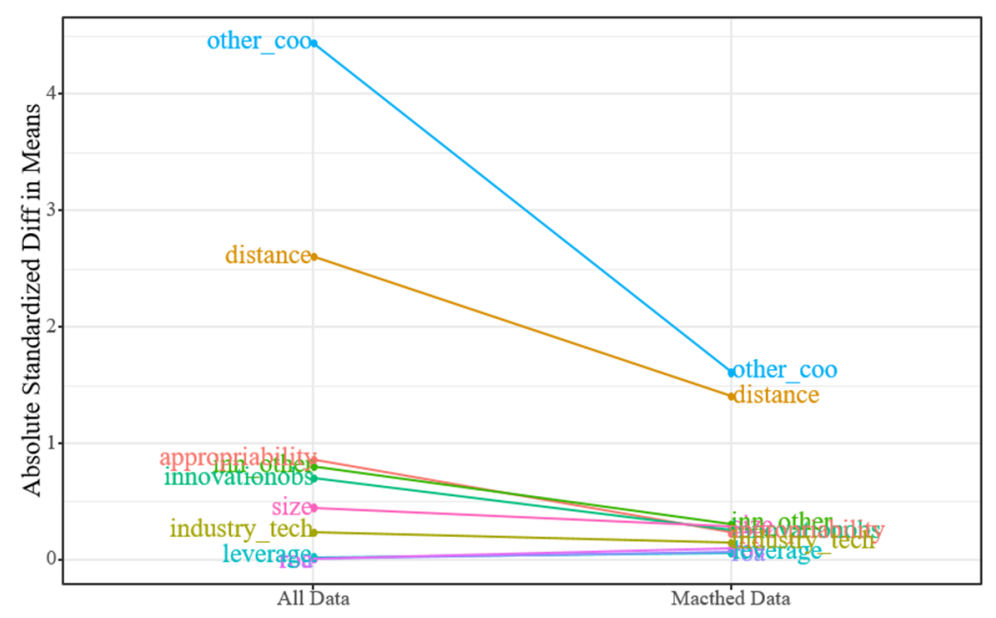

Figure A3. Change of absolute standardized differences for (KIS 2010). 


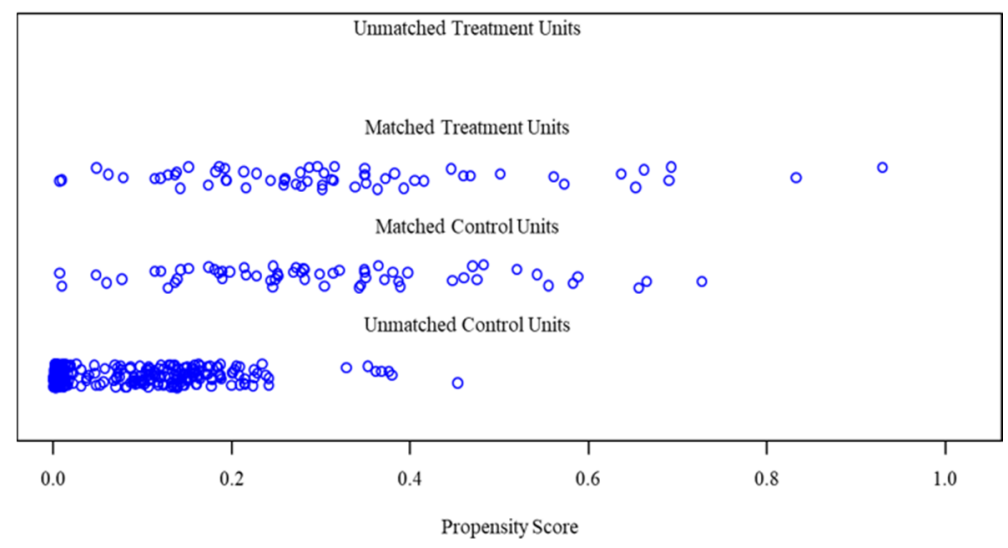

Figure A4. Distribution of propensity score (KIS 2014).
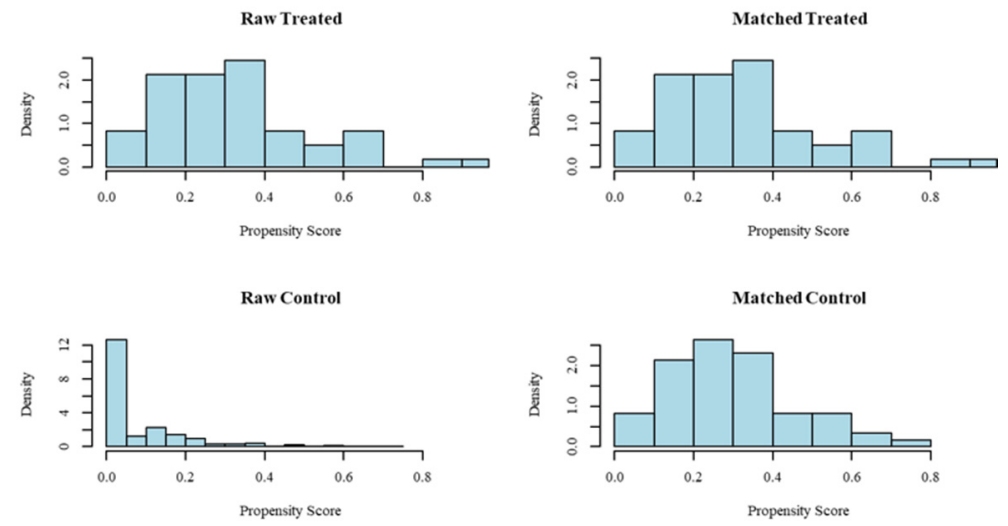

Figure A5. Histogram of propensity score (KIS 2014).

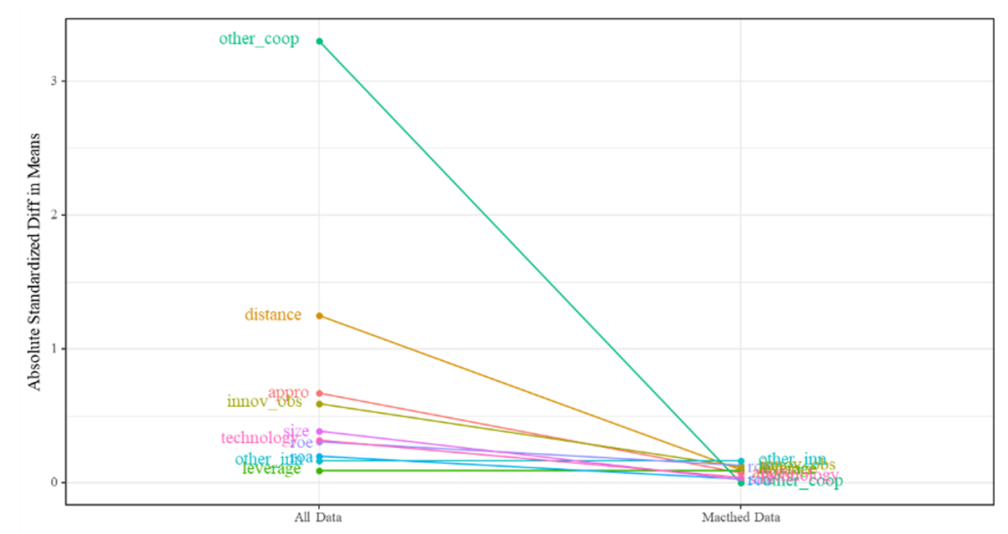

Figure A6. Change of absolute standardized differences (KIS 2014).

\section{References}

1. Gnyawali, D.R.; Park, B.-J. Co-Opetition and Technological Innovation in Small and Medium-Sized Enterprises: A Multilevel Conceptual Model. J. Small Bus. Manag. 2009, 47, 308-330. [CrossRef]

2. Gnyawali, D.R.; Park, B.-J. Co-Opetition between Giants: Collaboration with Competitors for Technological Innovation. Res. Policy 2011, 40, 650-663. [CrossRef]

3. Manzhynski, S.; Figge, F. Coopetition for Sustainability: Between Organizational Benefit and Societal Good. Bus. Strat. Environ. 2020, 29, 827-837. [CrossRef] 
4. Ritala, P.; Hurmelinna-Laukkanen, P. What's in It for Me? Creating and Appropriating Value in Innovation-Related Coopetition. Technovation 2009, 29, 819-828. [CrossRef]

5. Ritala, P.; Golnam, A.; Wegmann, A. Coopetition-Based Business Models: The Case of Amazon.Com. Ind. Mark. Manag. 2014, 43, 236-249. [CrossRef]

6. Chiambaretto, P.; Fernandez, A.-S. The Evolution of Coopetitive and Collaborative Alliances in an Alliance Portfolio: The Air France Case. Ind. Mark. Manag. 2016, 57, 75-85. [CrossRef]

7. Shih, M.H.; Tsai, H.T.; Wu, C.C.; Lu, C.H. A Holistic Knowledge Sharing Framework in High-Tech Firms: Game and Co-Opetition Perspectives. Int. J. Technol. Manag. 2006, 36, 354. [CrossRef]

8. Lai, K.-K.; Su, F.-P.; Weng, C.S.; Chen, C.-L. Co-Opetition Strategy from the Patent Analysis Perspective: The Case of the Stent Market. Int. J. Innov. Technol. Manag. 2007, 04, 137-153. [CrossRef]

9. Gueguen, G. Coopetition and Business Ecosystems in the Information Technology Sector: The Example of Intelligent Mobile Terminals. Int. J. Entrep. Small Bus. 2009, 8, 135. [CrossRef]

10. Okura, M. Coopetitive Strategies of Japanese Insurance Firms A Game-Theory Approach. Int. Stud. Manag. Organ. 2007, 37, 53-69. [CrossRef]

11. Wang, Y.; Krakover, S. Destination Marketing: Competition, Cooperation or Coopetition? Int. J. Contemp. Hosp. Manag. 2008, 20, 126-141. [CrossRef]

12. Shao, Y.-B. Analysis on the Game of Co-Opetition of Ports in the China Yangtze Delta -Taking Shanghai Port and Ningbo-Zhoushan Port as an Example. J. Navig. Port. Res. 2012, 36, 123-129. [CrossRef]

13. Harbison, J.R.; Pekar, P., Jr. Smart Alliances: A Practical Guide to Repeatable Success; Jossey-Bass: London, UK, 1998.

14. Brandenburger, A.; Nalebuff, B.J. Co-Opetition; Bantam Doubleday Dell Publishing Group: New York, NY, USA, 1996.

15. Walley, K. Coopetition: An Introduction to the Subject and an Agenda for Research. Int. Stud. Manag. Organ. 2007, 37, 11-31. [CrossRef]

16. Bouncken, R.B.; Gast, J.; Kraus, S.; Bogers, M. Coopetition: A Systematic Review, Synthesis, and Future Research Directions. Rev. Manag. Sci. 2015, 9, 577-601. [CrossRef]

17. Bengtsson, M.; Kock, S. "Coopetition” in Business Networks-To Cooperate and Compete Simultaneously. Ind. Mark. Manag. 2000, 29, 411-426. [CrossRef]

18. Ritala, P.; Sainio, L.-M. Coopetition for Radical Innovation: Technology, Market and Business-Model Perspectives. Technol. Anal. Strat. Manag. 2014, 26, 155-169. [CrossRef]

19. Peng, T.-J.A.; Pike, S.; Yang, J.C.-H.; Roos, G. Is Cooperation with Competitors a Good Idea? An Example in Practice: Is Cooperation with Competitors a Good Idea? Br. J. Manag. 2012, 23, 532-560. [CrossRef]

20. Dorn, S.; Schweiger, B.; Albers, S. Levels, Phases and Themes of Coopetition: A Systematic Literature Review and Research Agenda. Eur. Manag. J. 2016, 34, 484-500. [CrossRef]

21. Cygler, J.; Sroka, W.; Solesvik, M.; Dębkowska, K. Benefits and Drawbacks of Coopetition: The Roles of Scope and Durability in Coopetitive Relationships. Sustainability 2018, 10, 2688. [CrossRef]

22. Hoffmann, W.; Lavie, D.; Reuer, J.J.; Shipilov, A. The Interplay of Competition and Cooperation. Strateg. Manag. J. 2018, 39, 3033-3052. [CrossRef]

23. M'Chirgui, Z. The Economics of the Smart Card Industry: Towards Coopetitive Strategies. Econ. Innov. New Technol. 2005, 14, 455-477. [CrossRef]

24. Bengtsson, M.; Kock, S. Coopetition-Quo Vadis? Past Accomplishments and Future Challenges. Ind. Mark. Manag. 2014, 43, 180-188. [CrossRef]

25. Abernathy, W.J.; Clark, K.B. Innovation: Mapping the Winds of Creative Destruction. Res. Policy 1985, 14, 3-22. [CrossRef]

26. Utterback, J.M.; Suárez, F.F. Innovation, Competition, and Industry Structure. Res. Policy 1993, $22,1-21$. [CrossRef]

27. Teece, D.J. Firm Organization, Industrial Structure, and Technological Innovation. J. Econ. Behav. Organ. 1996, 31, 193-224. [CrossRef]

28. Ahuja, G.; Katila, R. Technological Acquisitions and the Innovation Performance of Acquiring Firms: A Longitudinal Study. Strateg. Manag. J. 2001, 22, 197-220. [CrossRef]

29. Amit, R.; Schoemaker, P.J.H. Strategic Assets and Organizational Rent: Strategic Assets. Strateg. Manag. J. 1993, 14, 33-46. [CrossRef] 
30. Sarasvathy, S.D. Causation and Effectuation: Toward a Theoretical Shift from Economic Inevitability to Entrepreneurial Contingency. Acad. Manag. Rev. 2001, 26, 243-263. [CrossRef]

31. Gnyawali, D.R.; Ryan Charleton, T. Nuances in the Interplay of Competition and Cooperation: Towards a Theory of Coopetition. J. Manag. 2018, 44, 2511-2534. [CrossRef]

32. Richardson, G.B. The Organisation of Industry. Econ. J. 1972, 82, 883. [CrossRef]

33. Fey, C.F.; Birkinshaw, J. External Sources of Knowledge, Governance Mode, and R\&D Performance. J. Manag. 2005, 31, 597-621.

34. Diestre, L.; Rajagopalan, N. Are All 'Sharks' Dangerous? New Biotechnology Ventures and Partner Selection in R\&D Alliances. Strateg. Manag. J. 2012, 33, 1115-1134.

35. Das, T. A Resource-Based Theory of Strategic Alliances. J. Manag. 2000, 26, 31-61. [CrossRef]

36. Le Roy, F.; Czakon, W. Managing Coopetition: The Missing Link between Strategy and Performance. Ind. Mark. Manag. 2016, 53, 3-6. [CrossRef]

37. Contractor, F.J.; Lorange, P. Cooperative Strategies in International Business; Lexington Books: Lexington, MA, USA, 1988.

38. Dyer, J.H.; Singh, H. The Relational View: Cooperative Strategy and Sources of Interorganizational Competitive Advantage. Acad. Manag. Rev. 1998, 23, 660-679. [CrossRef]

39. Kogut, B. Joint Ventures: Theoretical and Empirical Perspectives. Strateg. Manag. J. 1988, 9, 319-332. [CrossRef]

40. Nieto, M.J.; Santamaría, L. The Importance of Diverse Collaborative Networks for the Novelty of Product Innovation. Technovation 2007, 27, 367-377. [CrossRef]

41. Arranz, N.; Fdez de Arroyabe, J.C. The Choice of Partners in R\&D Cooperation: An Empirical Analysis of Spanish Firms. Technovation 2008, 28, 88-100.

42. Kang, K.H.; Kang, J. Does Partner Type Matter in R\&D Collaboration for Product Innovation? Technol. Anal. Strat. Manag. 2010, 22, 945-959.

43. Alves, H.; Ferreira, J.J.; Fernandes, C.I. Customer's Operant Resources Effects on Co-Creation Activities. J. Innov. Knowl. 2016, 1, 69-80. [CrossRef]

44. Devece, C.; Ribeiro-Soriano, D.E.; Palacios-Marqués, D. Coopetition as the New Trend in Inter-Firm Alliances: Literature Review and Research Patterns. Rev. Manag. Sci. 2019, 13, 207-226. [CrossRef]

45. Bauer, F.; Matzler, K. Antecedents of M\&A Success: The Role of Strategic Complementarity, Cultural Fit, and Degree and Speed of Integration: Antecedents of M\&A Success. Strateg. Manag. J. 2014, 35, $269-291$.

46. Park, B.-J.; Srivastava, M.K.; Gnyawali, D.R. Walking the Tight Rope of Coopetition: Impact of Competition and Cooperation Intensities and Balance on Firm Innovation Performance. Ind. Mark. Manag. 2014, 43, 210-221. [CrossRef]

47. Mansfield, E.; Rapoport, J.; Romeo, A.; Wagner, S.; Beardsley, G. Social and Private Rates of Return from Industrial Innovations. Q. J. Econ. 1977, 91, 221. [CrossRef]

48. Arrow, K.J. The Economic Implications of Learning by Doing. In Readings in the Theory of Growth; Palgrave Macmillan: London, UK, 1971; pp. 131-149.

49. Ritala, P.; Tidström, A. Untangling the Value-Creation and Value-Appropriation Elements of Coopetition Strategy: A Longitudinal Analysis on the Firm and Relational Levels. Scand. J. Manag. 2014, 30, 498-515. [CrossRef]

50. Belderbos, R.; Carree, M.; Lokshin, B. Cooperative R\&D and Firm Performance. Res. Policy 2004, 33, 1477-1492.

51. Le Roy, F.; Fernandez, A.-S. Managing Coopetitive Tensions at the Working-Group Level: The Rise of the Coopetitive Project Team: Rise of the Coopetitive Project Team. Br. J. Manag. 2015, 26, 671-688. [CrossRef]

52. Ding, Y.; Ma, L.; Zhang, Y.; Feng, D. Analysis of Evolution Mechanism and Optimal Reward-Penalty Mechanism for Collection Strategies in Reverse Supply Chains: The Case of Waste Mobile Phones in China. Sustainability 2018, 10, 4744. [CrossRef]

53. Fernandez, A.-S.; Chiambaretto, P.; Le Roy, F.; Czakon, W. Routledge Companion to Coopetition Strategies; Routledge: London, UK, 2018.

54. Quintana-García, C.; Benavides-Velasco, C.A. Cooperation, Competition, and Innovative Capability: A Panel Data of European Dedicated Biotechnology Firms. Technovation 2004, 24, 927-938. [CrossRef]

55. Guan, J.; Chen, K. Measuring the Innovation Production Process: A Cross-Region Empirical Study of China's High-Tech Innovations. Technovation 2010, 30, 348-358. [CrossRef] 
56. Cho, Y.; Lee, C. Effect of Coopetitive Activity on Innovation and Management Performances in the Structural Context. Sci. Technol. Soc. 2019, 24, 365-384. [CrossRef]

57. Von Zedtwitz, M.; Gassmann, O. Managing Customer Oriented Research. Int. J. Technol. Manag. 2002, 24, 165. [CrossRef]

58. Grimpe, C.; Sofka, W. Search Patterns and Absorptive Capacity: Low- and High-Technology Sectors in European Countries. Res. Policy 2009, 38, 495-506. [CrossRef]

59. Mizik, N.; Jacobson, R. Trading off between Value Creation and Value Appropriation: The Financial Implications of Shifts in Strategic Emphasis. J. Mark. 2003, 67, 63-76. [CrossRef]

60. Lindström, T.; Polsa, P. Coopetition Close to the Customer-A Case Study of a Small Business Network. Ind. Mark. Manag. 2016, 53, 207-215. [CrossRef]

61. Zhang, J.; Hoenig, S.; Di Benedetto, A.; Lancioni, R.A.; Phatak, A. What Contributes to the Enhanced Use of Customer, Competition and Technology Knowledge for Product Innovation Performance? Ind. Mark. Manag. 2009, 38, 207-218. [CrossRef]

62. Luo, X.; Rindfleisch, A.; Tse, D.K. Working with Rivals: The Impact of Competitor Alliances on Financial Performance. J. Mark. Res. 2007, 44, 73-83. [CrossRef]

63. Tsai, K.-H.; Hsieh, M.-H. How Different Types of Partners Influence Innovative Product Sales: Does Technological Capacity Matter? J. Bus. Res. 2009, 62, 1321-1328. [CrossRef]

64. Radicic, D.; Balavac, M. In-House R\&D, External R\&D and Cooperation Breadth in Spanish Manufacturing Firms: Is There a Synergistic Effect on Innovation Outputs? Econ. Innov. New Technol. 2019, 28, 590-615.

65. Caliendo, M.; Kopeinig, S. Some Practical Guidance for the Implementation of Propensity Score Matching. J. Econ. Surv. 2008, 22, 31-72. [CrossRef]

66. Charnes, A.; Cooper, W.W.; Rhodes, E. Measuring the Efficiency of Decision Making Units. Eur. J. Oper. Res. 1978, 2, 429-444. [CrossRef]

67. Cantner, U.; Westermann, G. Localized Technological Progress and Industry Structure: An Empirical Approach. Econ. Innov. New Technol. 1998, 6, 121-146. [CrossRef]

68. Madden, G.; Savage, S.J. Productivity Growth and Market Structure in Telecommunications. Econ. Innov. New Technol. 2001, 10, 493-512. [CrossRef]

69. Seiford, L.M.; Zhu, J. Profitability and Marketability of the Top 55 U.S. Commercial Banks. Manag. Sci. 1999, 45, 1270-1288. [CrossRef]

70. Paradi, J.C.; Rouatt, S.; Zhu, H. Two-Stage Evaluation of Bank Branch Efficiency Using Data Envelopment Analysis. Omega 2011, 39, 99-109. [CrossRef]

71. Chun, D.; Chung, Y.; Bang, S. Impact of Firm Size and Industry Type on R\&D Efficiency throughout Innovation and Commercialisation Stages: Evidence from Korean Manufacturing Firms. Technol. Anal. Strat. Manag. 2015, 27, 895-909.

72. Woo, C.; Chung, Y.; Chun, D.; Seo, H.; Hong, S. The Static and Dynamic Environmental Efficiency of Renewable Energy: A Malmquist Index Analysis of OECD Countries. Renew. Sustain. Energy Rev. 2015, 47, 367-376. [CrossRef]

73. Seo, H.; Chung, Y.; Chun, D.; Woo, C. Value Capture Mechanism: R \& D Productivity Comparison of SMEs. Manag. Decis. 2015, 53, 318-337.

74. Seo, H.; Chung, Y.; Yoon, H. R\&D Cooperation and Unintended Innovation Performance: Role of Appropriability Regimes and Sectoral Characteristics. Technovation 2017, 66-67, 28-42.

75. The World Bank. Manufacturing, Value Added. Available online: https://data.worldbank.org/indicator/NV. IND.MANF.CD? (accessed on 22 September 2020).

76. Woetzel, J.; Madgavkar, A.; Seong, J.; Manyika, J.; Sneader, K.; Tonby, O.; Cadena, A.; Gupta, R.; Leke, A.; Kim, H.; et al. Outperformers: High-Growth Emerging Economies and the Companies that Propel Them; McKinsey Global Institute (MGI): New York, NY, USA, 2018.

77. Shin, S.J.; Zhou, J. Transformational Leadership, Conservation, and Creativity: Evidence from Korea. Acad. Manag. J. 2003, 46, 703-714. [CrossRef]

78. Doh, S.; Kim, B. Government Support for SME Innovations in the Regional Industries: The Case of Government Financial Support Program in South Korea. Res. Policy 2014, 43, 1557-1569. [CrossRef] 
79. Bouncken, R.B.; Fredrich, V. Coopetition: Performance Implications and Management Antecedents. Int. J. Innov. Manag. 2012, 16, 1250028. [CrossRef]

80. Kylänen, M.; Rusko, R. Unintentional Coopetition in the Service Industries: The Case of Pyhä-Luosto Tourism Destination in the Finnish Lapland. Eur. Manag. J. 2011, 29, 193-205. [CrossRef]

(C) 2020 by the authors. Licensee MDPI, Basel, Switzerland. This article is an open access article distributed under the terms and conditions of the Creative Commons Attribution (CC BY) license (http://creativecommons.org/licenses/by/4.0/). 